TRAMES, 2009, 13(63/58), 4, 341-356

\title{
REPRESENTATIONS ABOUT DISCRIMINATION PRACTICES IN THE EDUCATION SYSTEM BUILT BY RUSSIAN AND UKRAINIAN IMMIGRANTS' CHILDREN IN LISBON METROPOLITAN AREA
}

\author{
Maria Manuela Mendes \\ Technical University of Lisbon.
}

\begin{abstract}
Based on a thorough qualitative study and interviews, this study presents a brief portrait of Russian and Ukrainian immigrants settled in the Lisbon Metropolitan Area (Portugal), with a particular focus on social representations and emotions that emerged in discriminatory contexts related with the educational system. Besides some initial difficulties and problems experienced by the immigrant's descendents, in general they actually have a successful insertion in the education system.
\end{abstract}

DOI: $10.3176 /$ tr.2009.4.02

Keywords: immigration, Russian immigrants, Ukrainian immigrants, social representations, discrimination, education system

\section{Introduction}

In this paper we will present some results of a wider and deeper research started in 2002, in which we tried to analyse the representations and the emotions concerning the discrimination against Russian and Ukrainian immigrants living in the Lisbon Metropolitan Area and in the Setúbal Peninsula.

We think that it is within the interaction framework that the representations concerning discrimination must be captured and conceptualized. It is important to realise how events, motivations and their effects occur, as well as the contexts of occurrence. From our point of view, a more dynamic, interactionist and relational perspective is, thus, defensible. The ethnic and national identity is built in a way and in a dialectic relation between the $I$ (Us) and the Others (Them), in which the individuals mobilize references, symbols and identitarian markers. Following Simmel's thought (1986) [1908], we took into account the perceptions of the differentiations between subjects as something inherent in interaction. The rela- 
tional character between the Us and the Others is portrayed not only in approximations and similarities, but also in oppositions and partings. Closely following Poutignat and Streiff-Fernart's (1995) contribution means that ethnic identity is the result of a set of representations that the interacting groups build whenever they are brought face to face.

The reason why we chose this particular subject is, to a great extent, its topicality in the context of the present-day Portuguese society, and also to show that we have filled considerable gaps in the national scientific production as far as this field and these ethnical groups are concerned. There are two main reasons to choose Russian and Ukrainian immigrants specifically: they are foreign noncommunitarian citizens with an immigration background in the national context, supposedly similar to the host society, at least visually (in terms of appearance) and in some cultural aspects as well. They seem to be fairly accepted by the majority of Portuguese society. We have chosen to study Russians and Ukrainians as a group, in spite of being heterogeneous groups in their core and among themselves, because they have some historical, cultural and geographic affinities. Until the 1990s they were both part of the former USSR. They view themselves as being the closest, namely among the biggest four Eastern European immigrant groups. Russians have not been subject of research at all in Portugal, probably due to their lack of visibility and their dimension, which is smaller than other Eastern European immigrant groups.

Analysing even further the reasons of our choice, focusing on each of the groups for analysis, it is undeniable that the immigration phenomenon from Eastern European countries is fairly recent in our society and it has not been properly studied until now. Until late 2004 the number of immigrants, with Permanence Permit, included 64730 Ukrainians (+1360 with Residence Permit), 7053 Russians (+1124 with Residence Permit), 12647 Moldavians and 10944 Romanians ${ }^{1}$. We suspect that these numbers might be bigger, if we add those that have not yet legalized their situation.

Regarding the empirical research itinerary and following a perspective of being closer to the 'real object', we use the following methodologies: documental analysis, statistical analysis and in-depth interviews. This approach will be led by two of the main mediations through which the transmission of social representa-

1 We only considered the four Eastern European nationalities with the biggest number of immigrants. In 2004 Portugal had 264222 foreigners with Residence Permits and 183832 with Permanence Permits (total conceded between 2001 and 2004). But in 2006 the number decreased: 37851 Ukrainians and 4945 Russians. This data was supplied by the Foreign and Frontiers Services in 2004 and 2005.

2 This research uses a research methodology strategy characterized by a certain pluralism and flexibility. We will tailor the techniques to each level and moment of analysis. This follows the research tradition known as constructivism, in which the main objective is to acknowledge the reality created through participated investigation (researcher and participant subjects), through which we aim to obtain the meanings and interpretations constructed by subjects. See Snape and Spencer (2004) "The Foundations of Qualitative Research" in Ritchie, J. and J. Lewis, (eds.) Qualitative research practice, Thousand Oaks, Sage Publications, pp.1-23. 
tions happens - language and discourse. As analysis material, we therefore prefer the testimonies gathered from 34 in-depth interviews with Russian and Ukrainian immigrants.

\section{The representations about the 'lived' and 'felt' discrimination: what is being discussed?}

The analysis presented in this article is centred on the social representation built by immigrants and apprehended through their oral speeches.

Our attention will focus on phenomena designated by the French authors (Guillaumin 1993 in Wieviorka; Balibar 1990; Taguief, 1987 and 1991; Wieviorka, 1991, 1993 and 1995, among others) as institutional racism, which is based on two inseparable ways of functioning: the one of differentiation and the one of hierarchism. The former derives from identitary, communitarian or cultural references, expressing itself in the rejection and exclusion of the Other, based on cultural difference (the cultural contrasts). The institutional racism does not necessarily refer to the political-administrative organisation, but rather to social practices that reflect "la marque du racisme" and that may assume "la forme de pratiques socials floues, presque incertaines..." (Bataille in Dewitt (dir.) 1999: 286). Or rather, they assume diffuse, little visible, banal, subtle, dissimulated configurations; therefore, such practices are sometimes devalued and not recognised by the victims themselves, because they understand them as socially legitimate. The hierarchisation is grounded on the inferiorisation of the Other and it corresponds to social processes which aim at placing the Other in a position of the discriminated and of the dominated.

Knowing about events more associated with institutional racism takes us further to the way some social spaces work, such as the housing market, the labour market, school, police intervention, etc. According to Philippe Bataille (1999), those diffuse and banal practices become socially legitimate, they are accepted as normal. The legitimacy of attitudes and discriminatory practices is based on an ideology whose grounds are negative representations, prejudices and stereotypes regarding the Other.

Both types of discrimination are not exclusive categories. They may coexist, and there are interconnections, though subtle, between institutional racism and cultural racism. This form of racism is grounded on the construction of the cultural difference, making difference essential, associating it with the construction of representations, prejudices and stereotypes that condition social relations. The difference is imposed from the outside, based on for example the ethnic, national or other origins, and that leads to treating the other in a different way. Referring to differentiation, Essed talks about the objectification of the Other, that is, the attitude that consists in not recognising the legitimacy of someone considered inferior, uncivilized, emotional or primitive (1991:200-1). Thus, the differences that separate the Other from the $I$ (Us) are overvalued and exaggerated. 
Rather than verbalised, differentiation is often felt, being rooted in the daily social relationships, in the language, habits, in the thought, in the access conditions to institutions, as well as to state resources (1991:194).

The objective is to analyse the representations of social practices and not the individuals, although this study is centred on the daily experiences of the individuals, caught through the verbal constructions concerning their experiences. We asked the interlocutors or narrators to situate those experiences in the social context they are involved. The context is a determining variable, taking into account the conditionings, the antecedents and the consequences inherent to the events reported by the interviewed. In this way, it makes sense to recall here the notion of 'everyday racism' as it is defined and used by Philomena Essed (1991). The author considers that racism is not strictly about the social structures and ideologies, but rather conceived: "as a process it is routinely created and reinforced through everyday practices" (1991:2). Thus, it is possible to conciliate the ideological and structured dimensions of racism and the cognitive components, as well as everyday attitudes and experiences. This form of manifestation "is racism, but not all racism is everyday racism" (Essed 1991:3), involving systematic, recurrent, familiar and banal social practices ${ }^{3}$. Everyday racism is a multidimensional phenomenon and its analysis implies a conciliation between the two interactionist perspectives with the micro-localized character and macro and structuralist theories. Thus we try to get to know and understand everyday experiences, exploring both experiential and cognitive dimensions. The emotions experienced in these events emerge in this analysis context as one more dimension of human experience, probably the less visible and less controlled. Its interiority makes the externalization difficult, namely the verbalisation and apprehension in a research context.

Since the end of the nineties of the last century, the social psychologists have renewed their interest in the function of emotions as one of the critical components of the intergroup attitudes. J.-Philippe-Leyens et al. (2002) consider that the most basic reaction towards strangers is emotional; in this way, the contemporary theories of prejudice tend to transfer the centre of analysis to its emotional dimensions (Mackie and Smith, eds.: 149). Thierry Devos et al. (2002) also affirm that the effective answers concerning national, ethnic and religious groups are more consistent and reliable predications of attitudes of social distance (Mackie and Smith, eds.: 111-34).

In this context, and starting from the presumption that the discrimination occurs in a situation of interaction, we try to give an answer to several questions, such as: how does discrimination occur, namely in school context? Who are perpetrator agents and what are their motivations? But it is also important to have access to representations, behaviour reactions and emotions experienced by subjects.

3 Philomena Essed (1991), clarifies that "everyday racism is infused into familiar practices, it involves socialized attitudes and behavior. Finally its systematic nature indicates that everyday racism includes cumulative instantiation." They are "practices prevalent in a given system". p. 3. 
In this analysis context, we privileged the narratives about personal experiences or situations lived by people with whom the narrators have affective proximity links, as well as the representations and the emotions about some events.

\section{Brief socio-demographic characterisation of the interviewed immigrants}

Among the interviewees there is a bigger sample of men than women (19 to 15), a discrepancy that is even more notable among the Ukrainian interviewees (12 men and 8 women). Among the Russian interviewees, the male/female ratio is quite balanced ( 7 of each gender). This observation not only reflects the demographic situation of the interviewed groups in this specific study, but actually also reflects the macro numbers of the migratory flows. Immigration from Ukraine is substantial and mainly composed of men, while immigration from Russia shows more proportional numbers between men and women. Female Russian immigration reflects the emancipation trajectories undergone due to the weakening and fragilization of their status, following the fall of the social and political system in the Soviet Union. The policies implemented by Gorbachev in 1987 with perestroika ${ }^{4}$ implied the economy's restructuration as a way to modernize communism, organize the economy and implement the glasnost ${ }^{5}$ (opening). These policies caused a severe economical, social and political crisis. Ultimately, the intensification of ethnical, social and ecological tensions felt in its republics, and political problems led to the fall of the Soviet Union.

The fall of the Soviet Union and the independence of some of its former republics took place in the early 1990s. Ukraine became independent on 24 August 1991. Following that, the Russian Federation put in motion a transition period in the market economy, a hard process filled with problems, tensions and antagonisms. In 1988, there was a financial crisis with the depreciation of the rouble; this immediately had a significant impact on the population life conditions. According to some sources ${ }^{6}$, in 1999 , around $20 \%$ of the Russian population lived below the poverty line. In 2001 the unemployment rate reached $8.7 \%$, a number that does not account for the invisible but undeniable dimension of sub-employment. Moreover, if the loss of prestige, the drop of some professions' pay rates and their social recogni-

4 Economical restructuration project started in 1986. Among other things, it included the reintroduction of market economy mechanisms and the right to private property in different sectors of economy, transforming military industries into producing consumption goods. In http://www.conhecimentosgerais.com.br/historia-geral/fim-da-urss

5 Political transparency - it was one of the core elements to undertake a change in behaviours and mentalities, in order to develop a political will, which would become a national design aiming to implement reforms. Among other aspects, it announces the end of political dissidents' pursuit and cultural liberalization. For a deeper view on this subject, see http://www.conhecimentosgerais. com.br/historia-geral/fim-da-urss.

6 Pereira Coutinho Almeida \& Partners, Gestão de operações internacionais (2002) in http://www.Pereiracountinho.com/pt/rússia.html; http://www.conhecimentosgerais.com.br/ historia-geral/ fim-da-urss.html; http://pt.wikipedia.org 
tion and the growth of unemployment affected the general population, they clearly affected even more the highly qualified Russian women. On the situation of Russian women, the International Organization for Migration (IOM) highlights: "Unemployment has had a disproportionate impact on these educated women. Concomitantly they lost their workplace benefits and childcare facilities with the closure of the workplace." (IOM 2002:8). Consequently, the between early and late 1990s, female unemployment rate increased from 60 to $80 \%$ in some regions, even reaching $90 \%$ in others. For many women there was no other solution but to leave the country, in search of better employment conditions.

The situation in Ukraine was very similar - massive unemployment, trouble in maintaining minimum subsistence levels, low pay rates, poverty ${ }^{7}$ and mainly the fact that in the late 1990s "the exclusion of women from the "formal and regulated labor market' contributes to creating a strong push factor for women to seek work abroad" (IOM 1998:4). Ukraine is considered by IOM as one of the main European countries where the traffic of women and children for forced prostitution or sexual exploitation reaches the highest levels ${ }^{8}$. According to a report published by IOM, from 2000 to September $1^{\text {st }} 2003$ "over 900 victims of trafficking have been assisted by IOM" in Kiev (Lisa-Jo Baker and Paul Miasnikoff, IOM: 3). Fighting this crime is made even harder by its highly profitable nature, and the fact that its legal definition is still quite ambiguous and equivocal. Portugal was also one of the destinations of these victims. However, the number of women in the migration flow is smaller, especially those from Ukraine, probably due to a two-folded reason: once inside the country, immigrants are immediately channelled to work in the construction industry or on public works, and the likely 'tradition' that pushes the man to be the one to leave the country first in an initial immigration phase.

In the qualitative sample chosen as interviewees, the main tendency is for a male majority (12 Ukrainians and 7 Russians). Still, the number of women is also significant (8 Ukrainians and 7 Russians). The interviewees' age ranges from 20 to 60 years, the two main groups are in their twenties and in their forties, which indicates the presence of a contingent slightly older than what is usual in labour-

7 During 1990/98, the Gross Internal Product fell 11.9\%, in 1993 inflation reached 10 000\%, in http://www. bbc.co.uk.portuguese/noticias/2001/01126_urssukraine.shtml

8 According to IOM's delegation in Ukraine: "Most victims of trafficking from Ukraine are female, between the ages of 22 and 27. Of the 921 victims IOM has assisted since 2000 through to 1 September 2003, 96\% were women. The few cases of trafficking in men, which were handled by IOM, were cases of forced labor in different countries of destination, including: the Russian Federation, Turkey, the Czech Republic, Portugal and Spain. But the majority of Ukrainian victims of trafficking assisted by IOM are women. While they are trafficked for a variety of purposes such as pornography, forced labor and other economic exploitation, participation in criminal activities such as organ removal; and begging, the vast majority of victims are being trafficked for the purpose of forced prostitution and sexual exploitation. The IOM caseload in Ukraine clearly reflects this fact. And even when women are trafficked for other purposes, sexual exploitation commonly occurs. (...) Traffickers often use the cover of a travel, employment recruiting, or marriage agency, and arrange documents and travel across one or more international boundaries. From the initial recruitment to arrival in the country of destination, traffickers may sell the young women a number of times." ((IOM 2002), pp. 3-4) 
related migrations. This fact cannot be dissociated from wider social and political dismemberment processes, as well as the present economical destruction lived in these countries. The active population has no choice but to leave the country in search of better opportunities when faced with high levels of unemployment and the depreciation of their present pay rates. The presence of such a big number of immigrants of working age, underlines once more that we are dealing here with an immigration triggered essentially by economic and work reasons. This is confirmed by previous analysis of the national context, e.g. the research done in 2002 by Baganha, Góis and Marques, using a quantitative methodology. The authors identified that more than $70 \%$ were men, around 36 years old, leading to the unequivocal conclusion that we are facing a migration flow of working age male adults (Baganha and Fonseca (coord.) 2004:33).

As far as the interviewees' level of education is concerned, almost all have a diploma of some kind of studies beyond secondary school, which duration ranges from 1 to 5 years. Unlike other migration flows in our country, Ukrainian and Russian are generally highly qualified, regardless of gender.

Nevertheless, there is not really a sociocultural homogeneity among the interviewees. Actually, among Russians and Ukrainians there are minor, though perceptible, differences. On the one hand, Russians ${ }^{9}$ seem to have higher qualifications than Ukrainians. On the other hand, there are slight gender asymmetries: men present somewhat higher levels of education than women, more noticeable in postsecondary school studies $-60 \%$ of males ( 12 men) have a diploma with 4 or more years duration, while on the female side the number drops to $30 \%$ (5 women).

Table 1. Education level according to gender

\begin{tabular}{l|c|c|c}
\hline \multicolumn{1}{c|}{ Education level } & Male & Female & Total \\
\hline 1-4 years & & 1 & 1 \\
5-6 years & - & - & - \\
7-9 years & 1 & - & 1 \\
10-12 years & 3 & 3 & 6 \\
Post-sec. 1-3 years & 3 & 6 & 9 \\
Post-sec. 4+ & 12 & 5 & 17 \\
$\quad$ Total & 19 & 15 & 34 \\
\hline
\end{tabular}

More than $75 \%$ of interviewees (26 individuals) have a diploma of standard or advanced studies. Nonetheless, it is also true that $44 \%$ take up jobs that require little or no qualifications and are therefore unrelated to the acquired education capital. Baganha, Góis and Marques (2004) found out that 69\% of Eastern European immigrants questioned in 2002 had finished secondary school or a technical/professional school, $10 \%$ had a BA and around $21 \%$ had at least one

9 Notice that this was also identified in the late 1990s, among migration flows from Central and Eastern Europe, that settled in France, right after the fall of the USSR. See Anne de Tinguy and Alexandra Picard (1999) in Dewitte (org.), p. 158. 
advanced degree (in Baganha and Fonseca (coord.) 2004:33). Of this group 62.1\% were doing non-qualified jobs. The discrepancy between their qualifications and their current jobs reveals how the potential of this manpower with qualifications higher than the national offer is clearly being wasted.

Regarding the number of children, there is a clear prevalence of interviewees with 2 children ( 11 interviewees, all over 30 years old), closely followed by interviewees with a single child (10, of which only 3 are in their 20s). However, it is important to underline that 10 of them $(\mathrm{N}=34)$ still have no children; around $80 \%$ of these are under 29 years old. The average is of 1.2 children per family.

Some small contrasts appear between these two migrant groups. The main differentiation factor is the presence of their children in the host country. More than half of the Russians brought their children along and just 2 interviewees had left their in Russia. On the other hand, most Ukrainians (more that 70\%) left their children in Ukraine, while the rest live with one or more kids. For these immigrants, moving to Portugal implied a social and spatial separation from their children. It is noteworthy that the immigrants who left behind some or all their family, manage their income in the host country in a very disciplined and closely controlled way, sending home monthly amounts. One of the main worries they have that to some extent also motivated their departure is the need to face the expenses of their children's education.

However, at least during the initial period of arrival in the host society, most of these immigrant are deprived from any informal social support structure, as all their relatives and friends are still in their country of origin. Some of the researchers who study migration flows from Eastern Europe since 2000/1 (Baganha e Fonseca (coord.) 2004a) have identified in its interior two subgroups: a smaller one that chose to move permanently, bringing their family along and revealing a certain residential stability; and a bigger group that regards their stay in Portugal as a temporary experience, they left their families in their countries of origin and intend to return; they usually live in more precarious lodgings (spaces supplied by their employers, hostels, shared rooms or apartments). The majority of all interviewees live in the host country with their spouse (or partner), while $1 / 3$ lives isolated and without relatives, usually sharing their home with friends or even mere acquaintances.

Table 2. Who do immigrants live with, according to nationality

\begin{tabular}{l|c|c|c}
\hline \multicolumn{1}{c|}{ Who do they live with? } & Russian & Ukrainian & Total \\
\hline Alone & - & 1 & 1 \\
Alone with their children & 1 & - & 1 \\
With friends and acquaintances & 4 & 7 & 11 \\
With parents and siblings & 1 & 1 & 2 \\
With their partner & 2 & 2 & 4 \\
With their partner and other people & - & 5 & 5 \\
With their partner, children and other people & 1 & 2 & 3 \\
With their partner and children & 5 & 2 & 7 \\
$\quad$ Total & 14 & 20 & 34 \\
\hline
\end{tabular}


We highlight that the majority of couples living together with or without their children, also tend to share their home with more people, in an attempt to cut their monthly expenses.

There is a certain kind of polarization in the most common residential situations: 19 individuals live with their partners, 10 of whom live with their children; 11 live with friends and acquaintances, more than half (19) still share their home with others. These numbers contradict Lucinda's study ((coord.) 2005:84 and 116) on the reunification of immigrant families, stating that more than half of the observation group lived alone (35\%) or with one or two relatives $(37.9 \%)$. This situation probably corresponds to the first years of permanence in Portugal (2000 2002), though afterwards some changes took place, leading to increasing cases of family reunifications and a residency emancipation of family groups, due to a rising professional, economical and juridical stability.

\section{The immigrants' representations in contexts and situations of discrimination: the education system in the host country}

Immigrants from the former USSR tend to be able to share more easily the discriminatory experiences at work, but seem a bit more reluctant to talk about situations that take place in other contexts. Nevertheless, we try to "look beyond the façades" of the stereotyped and iterative discourse interviewees tend to produce.

This study presents exclusive cases of prejudice where the immigrants felt particularly discriminated in the education system and the school contexts where their children are.

Generally the interviewees think that their children adapt well to the Portuguese education system and quickly learn the language, which is always the biggest challenge faced by a newcomer.

Natasha only sent the oldest child to school, two months before the end of the school year. She was afraid he would not be "well received". And as a matter of fact he showed some psychosomatic reactions typical of inadaptation: "but he went to school. And... threw up every day. And we thought maybe the child has something". Afterwards, as the environment at school improved, these reactions eventually disappeared:

"In Portuguese language and in other subjects, because it's obvious that he
couldn't know beforehand Portugal's geography or history. English started
here, because with what he accomplished in 2 months, he couldn't pass, but they
made him simplified tests and he ended up passing the year. It was a huge
support from the ...school teachers." (Natasha, 37 years old, Ukrainian,
legalized, married, 2 children, technical intellectual and scientific staff)

In the interview, Natasha confesses she was pleasantly surprised that her younger daughter "was so well received!", quickly fitting in the school environment. Surprised and happy, she remembers how at home her daughter would repeat over and over, "such nice people". 
Maria is only 10 years old. She is in the $4^{\text {th }}$ grade and says she never felt rejected by her classmates, teachers or other staff. Still, sometimes the other students would call her "Russian" and she does not like it:

Some are a little rude, they call...

And with you, have they ever been rude?

Sometimes.

When does this happen?

Sometimes in the playground, in classes.

(Maria, Russian, student, came to Portugal with her family).

Zina has three children, two came to Portugal and one remained in Russia. She mentions their initial trouble at school, felt especially by her younger son, now aged 15. She say his initial adaptation was not easy because other kids picked on him and would say "go back to your own country..." Zina also says that he avoids contact with African kids, namely in other situations or contexts of youth interaction:

Son say in Internet these African kids, then lots of noise, lots of... shouting, lots AHHH, this work woman, men, and then... doesn't like, my son doesn't like black kids on Internet.

And where does your son go on the Internet?

Brandoa Library... all... this.

(Zina, 45 years old, Russian, legal, BA, unemployed (unqualified service worker).

Also Nicolai complains about a "little bit of racism" the other kids show at school. In his opinion kids simply mimic the opinions and behaviours they hear and observe in their family or in their broader social environment. For Nicolai, the parents are definitely responsible:

“(...) because... talk with fathers, mothers at home and a lot of people don't like us... because us, like they think and like them I saw on the TV, we harm others, we work Portuguese work, they don't have work and we do this work and... here there are lots of racisms!" (Nicolai, 33 years old, Ukrainian, legal, married, advanced education, construction worker)

Nicolai's son is 12 years old and is now finishing the $5^{\text {th }}$ grade, in the year before he had trouble in the relationship with his classmates. Besides having to endure the same comments as Zina, he also suffered physical aggression from a group of teenagers. Nicolai was appalled by the school director's lack of interest in the matter. He decided to take the matter into his own hands and intimidate the group of teens abusing his son:

They hit outside school, 3, not 1, 1 is only 1, no, 2, 3, 4 people. (...) I talked with those 4 persons and after...

Did the trouble stop there?

Because I talked very... very stressed. Angry. 
Did they react or say something?

They? One person only said that... he also said something bad to them he yes 'well, he talks something bad to you, then you talk to him, you talk to director, you talk to him alone, not with 3 others', one to one, that is normal. If it's 3 to one, 4 to one, that's wrong, wrong.

(Nicolai, 33 years old, Ukrainian, legal, married, advanced studies, construction worker)

At school, peer pressure is one of the main influences of acceptance or adaptation of Eastern European children and youths.

Viktor's brother is 17 years old and was half way through the $10^{\text {th }}$ grade when he left school. The same happened with Viktor's girlfriend, a Russian girl aged 15. According to Viktor, both left school because they had trouble with their classmates. Viktor tells us in detail the rejection felt by his girlfriend. Apparently all went well during the first year in the Portuguese education system. The problems appeared the following year, when she started in a new class. She was bullied, not so much by the boys, but especially by the other girls:

(...) they were always saying - 'look you, leave our school, you don't let us study, no one likes you here, you are mean, no one likes you here, neither the boys nor the girls'; and she was always angry with this and was always crying, so she left school as well. (Viktor, 20 years old, Ukrainian, legal, $10^{\text {th }}$ grade, administration, commerce and services staff)

The girl eventually left school during the $8^{\text {th }}$ grade, due to personal suffering caused by this peer pressure, in the form of verbal violence.

Inna is 26 years old, Russian nationality and Ukrainian citizenship. She says she is very close to a Russian girl, aged 10, who used to attend the same Orthodox church, and who, despite having been several times the victim of aggression, has not yet left school.

The higher quality of the education system in Russia and Ukraine, compared to Portugal, is a recurrent issue in these immigrants' testimonies. They identify a huge discrepancy between the teaching in equivalent grades, in terms of the curriculum's complexity and demand. Nina is Ukrainian and says that "there everything is much harder... or school leads the way". She adds that children who leave school in Ukraine and start in Portugal end up suffering a significant "setback", not only in their school evolution, but also in their intellectual development. Nina highlights the dissatisfaction and frustration felt by these kids, and tells the story of a kid she knows:

(...) a kid who is delayed 2-3 years; the kid becomes stupid here, she is an Ukrainian kid who went to the $5^{\text {th }}$ grade and she knew things and made questions that neither the classmates nor the teacher could answer and they envied her because of that; she felt really bad. (Nina, aged 40 , legal, $10^{\text {th }}$ grade detained)

Other interviewees criticize different aspects concerning the way the education system works. For instance, Dima questions the logic in having new school 
manuals every year. In her opinion, the state does not think of the families with less resources at all, "they don't ask themselves if a person has money or not to buy this book". Ukraine has a very different system:

(...) for instance, once I finished reading this book, it would pass to someone after me, and the same thing had happened to me, and the curriculum was the same. For example in languages, mathematics, geography, all remains the same year after year. Therefore, I don't think it's worth to come up with new curricula just for someone to make money out of it. (Dima, aged 28, Ukraine, legal, advanced studies, construction worker)

This interviewee, who is also President of an Immigrant Association, says how easily the students master the new media, but also mentions that schools ignore some families, namely immigrant families, who might not have economical resources to acquire computers. Dima adds that there are also “(...) schools that demand homework to be done with the computer, not asking if the student has computer, and if they don't do it, they have a bad mark, and after 3 bad marks they fail the school year..." (Dima)

Jenna, Olga's daughter, experiences these problems on a daily basis. Jenna is 15 years old and studies in the $8^{\text {th }}$ grade. She already asked her mother for a computer, but the family budget does not allow such a big expense. Olga says: "you have a lot of computer, that is very good; in Ukraine very few, very few school class that has computer, here is good, I like it (...). Our daughter wants computer very much but I say: 'Jenna, it's very expensive'”. (Olga, aged 40, Ukrainian, legal, married, 2 children, technical education, unqualified service worker)

\section{Final remarks}

Due to the recent history of Russian and Ukrainian immigrants, with a main influx in 2000-2002 and a reflux in the last 5 years, there is yet not enough empirical data of their children's social integration. What we can ascertain this far is that they actually have a successful insertion in the education system in regards to math and natural sciences.

Regarding the events portrayed here that involve inter-ethnical and discriminatory interaction, certainly there is a subconscious impact that will hardly ever be verbalized or expressed during these interviews. As these immigrants reveal a certain economy of gestures and emotions regarding these discriminatory events, a body language and behavioural analysis would probably infer repressed, hidden or dissimulated feelings, not clear at first glance. Russian and Ukrainian immigrants are "silence minorities", they choose silence, invisibility strategies, even when they are being harmed and put to disadvantage by Others (majority or minorities).

Despite some changes and singularities, the continuity and persistency (regularities) of a social, cultural and ethnical displacement is significant and still constitutes the main tendency. 
Table 3. Table synthesis showing discrimination areas and events, and immigrants' reaction, within the school context

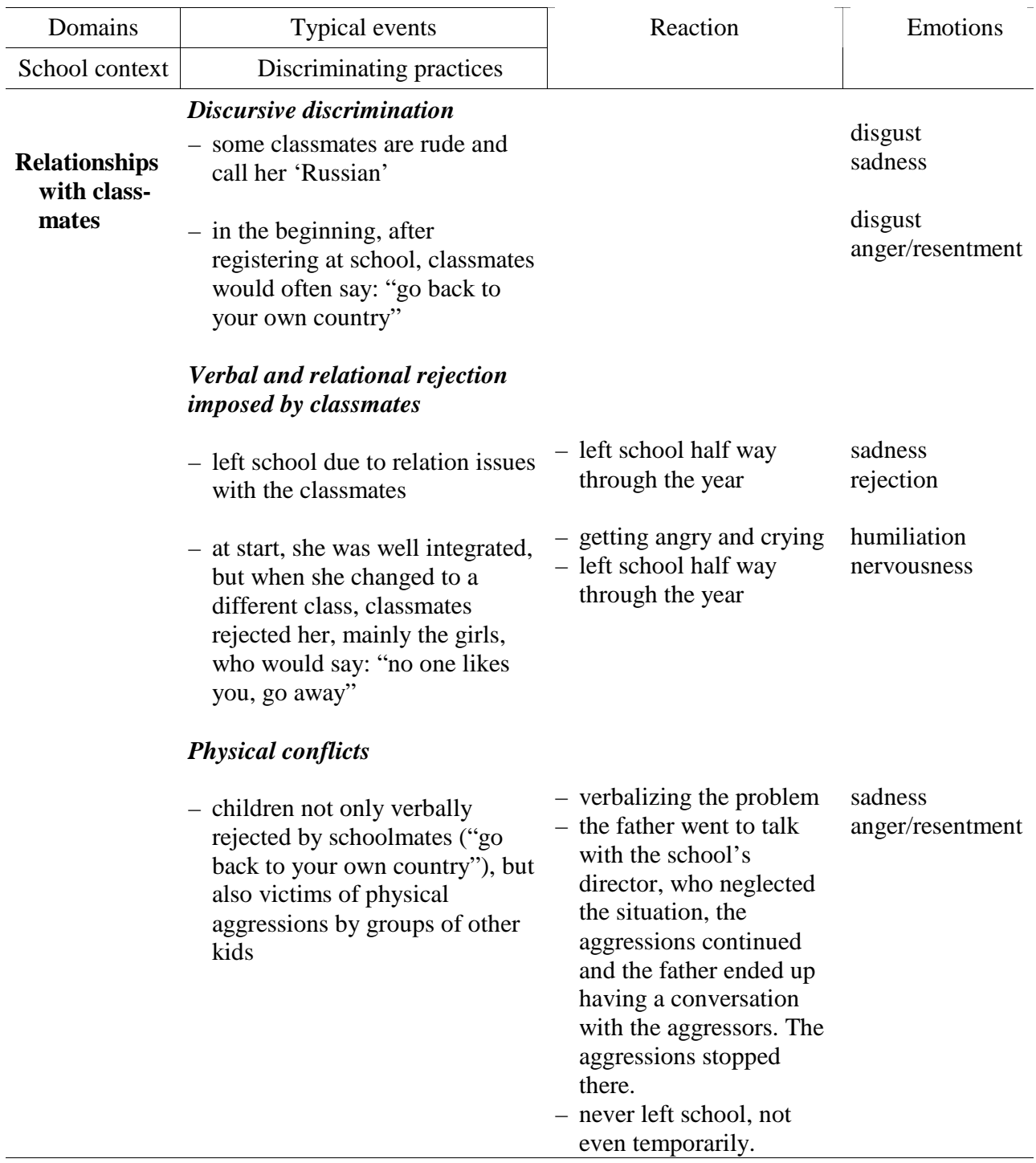

\section{Acknowledgements}

This text is based on one of the chapters of the doctorate dissertation in General Sociology which is being developed between 2002 and 2007 at the Institute of Social Sciences of the University of Lisbon (ICS - UL). 
Address:

Maria Manuela Mendes

Faculdade de Arquitectura da Universidade Técnica de Lisboa

Rua Sá Nogueira

Pólo Universitário

Alto da Ajuda

1349-055 Lisboa, Portugal.

E-mail: mamendesster@gmail.com

Tel.: 0351213615000

Fax: 0351213647066

\section{References}

Baganha, I., et al. (2004a) "The unforeseen wave: migration from Eastern Europe to Portugal". In New Waves: Migration from Eastern to Southern Europe, 23-39. Baganha e Fonseca, eds., Lisbon: Luso-American Foundation.

Baganha, I., et al. (2004b) "Immigrants and the labour market: the Portuguese case". In Metropolis International Workshop - Proceedings, 89-120. Luso-American Foundation, pub., Lisbon: Luso-American Foundation.

Baker, Lisa-Jo and Paul Miasnikoff (2003) EECA Ukraine country report. IOM.

Barth, Fredrik ed. (1982), Ethnic groups and boundaries: the social organization of culture difference. Bergen/Oslo: Universitetsforlaget.

Bataille, Philippe (1999) "Racisme institutionnel, racisme culturel et discriminations". In Immigration et Intégration, 285-293. Phlippe Dewitte, dir. Paris: La Découverte.

Bourdieu, Pierre et al. dir. (1993) La misère du Monde. Paris: Éd. du Seuil.

Castles, Stephen (2000) Ethnicity and globalization. London: Sage Publications Lda.

Corkill, David and M. Eaton (1999) "Multicultural insertions in a small economy: Portugal's immigrant communities". In Immigrants and the informal economy in Southern Europe, 149-168. M. Baldwin-Edwards and J. Arango, eds. London: Frank Cass Publishers.

Costa, António Firmino da (1999) Sociedade de Bairro: Dinâmicas Sociais da Identidade Cultural. Oeiras: Celta Editora.

Devos, Thierry et al., (2002) "Experiencing intergroup emotions". In From prejudice to intergroup emotions: differenciated reactions to social groups, 111-314. M. Diane Mackie and Eliot R. Smith, eds. New York and Hove: Psychology Press.

Essed, Philomena (1991) Understanding everyday racism: an interdisciplinary theory. Newbury Park, California: Sage Publications.

Fonseca et al. (2005) "Portugal". In Current immigration debates in Europe: a publication of the european migration dialogue, 325-354. Niessen et al., eds. Brussels: Migration Policy Group.

Fonseca M. Lucinda and J. M. Malheiros, coords. (2005) Social integration and mobility: education, housing and health. (IMISCOE Cluster B5 State of the Art Report). Lisboa: CEG.

Fonseca, M. Lucinda (coord.) (2005). Reunificação familiar e imigração em Portugal: Relatório final. Lisboa: CEG.

Fonseca, Maria Lucinda et al., (2004) "immigration to medium sized cities and rural areas: the case of Eastern Europeans in the Évora region (Southern Portugal)". In New Waves: Migration from Eastern to Southern Europe, 91-118. Baganha e Fonseca, eds. Lisbon: Luso-American Foundation.

Goffman, Erving (1988) [1963] Estigma: notas sobre a manipulação da identidade manipulada. Rio de Janeiro: Editora Guanabara.

Guillaumin, Colette (1993) "La «différence culturelle»". In Racisme et modernité, 149-151. Michel Wieviorka, dir. Paris: Éditions La Découverte. 
Hoosen, David (1994) "Ex-Soviet identities and the return of geography". In Geography and national identity, 134-140. D. Hoosen, ed. Oxford, Blackwell.

Hughes, Donna M. (2002) Trafficking for sexual exploitation: the case of the Russian Federation. Geneva: IOM.

IOM (International Organization for Migration) (1998) Research Report. Geneva: IOM.

Jodelet, Denise (1994) "Représentations sociales: un domain en expansion". In Les représentations socials, 32-61. Denise Jodelet, dir. Paris: PUF.

King, Russel e Natália Ribas-Mateos (2005) "Migração Internacional no Mediterrâneo: «o Modelo do Sul da Europa»”. In Globalização e Migrações, 191-221. António Barreto, org. Lisboa: ICS.

Lapeyronnie, Didier (1993) L'individu et les minorités. La France e la Grande-Bretagne face à leurs immigrés. Paris: PUF.

Machado, Fernando Luís (2003) "Imigração e Imigrantes em Portugal: parâmetros de regulação e cenários de exclusão". Sociologia Problemas e Práticas 41, 183-188.

Malheiros, Jorge Macaísta (2005) "Jogos de Relações Internacionais: repensar a posição de Portugal no arquipélago migratório global”. In Globalização e Migrações, 251-272. António Barreto, org. Lisboa: ICS.

Miles, Robert and Malcolm Brown (2003) Racism. London and New York: Routledge.

OIM (2002) "Exploitation: report on the Russian Federation. In Traite des Migrants, n 25. Genève: OIM.

Pettigrew, Thomas F. et R. W. Meertens (1993) "Le racisme voilé: dimensions et mesure". In Racisme et Modernité, 109-126. Michel Wieviorka, dir. Paris: Ed. La Dècouverte.

Philippe-Leyens, J. et al. (2002) "Expressing emotions and decoding them, ingroups and outgroups do not share the same advantages". In From prejudice to intergroup emotions: differenciated reactions to social groups, 135-151. M. Diane Mackie and Eliot R. Smith, eds. New York and Hove: Psychology Press.

Pires, Rui Pena (2002) "Mudanças na imigração: uma análise das estatísticas sobre a população estrangeira em Portugal, 1998-2001”. Sociologia Problemas e Práticas 39, 151-166.

Portes, Alejandro (1997) "Theory for a new century: some problems and opportunities". International Migration Review 31, 799-821.

Poutignat, Philippe et Streiff-Fenart, Jocelyne (1995) Théories de l'ethnicité. Paris: PUF.

Ritchie, J. and J. Lewis, eds. (2004) Qualitative research practice. Thousand Oaks: Sage Publications.

Rocheron, Yvette (1999) "Les mariages mixtes, un indice anthropologique de l'assimilation". In Immigration et integration, 205-211. Phlippe Dewitte, dir. Paris: Éditions La Découverte.

Satzwich, Vic (2002) The Ukrainian diaspora. London and New York: Routledge.

Scheff, Thomas J. (1994) "Emotions and identity: a theory of ethnic nationalism". In Social theory and the politics of identity, 277-303. C. Calhoum, ed. Oxford: Blackwell.

Scheff, Thomas J. (1997) Emotions, the social bond, and human reality: part/whole. Cambridge: Cambridge University Press.

Shah, J. Y., P. B., Brazy, and E. T. Higgins (2002) "Promotion and prevention forms of ingroup bias". In from prejudice to intergroup emotions: differenciated reactions to social groups, 31-48. M. Diane Mackie and Eliot R. Smith, eds. New York and Hove: Psychology Press.

Shulman, Stephen (1999) "The cultural foundations of Ukrainian national identity". Ethnic and Racial Studies 22, 6, 1011-1036.

Shulman, Stephen (2004) "The contours of civic and ethnic national identification in Ukraine". Europe-Asia Studies 56, 1, 35-56.

Simmel, G. (1986) [1908] “Digresión sobre el extranjero". In Sociologìa 2. Madrid: Alianza Ed.

Snape and Spencer (2004) "The foundations of qualitative research". In Qualitative research practice, 1-23. J. Ritchie and J. Lewis, eds. Thousand Oaks: Sage Publications.

SOPEMI (2001) Tendances des migrations internationales. Rapport Annuel. Paris: OCDE.

Stephen, Walter G. and C. Lausanne Renfro (2002) "The role of threat in intergroup relations. In From prejudice to intergroup emotions: differenciated reactions to social groups, 191-207. M. Diane Mackie and Eliot R. Smith, eds. New York and Hove: Psychology Press. 
Tabloni, Simonetta (2001) "Il n'y a pas de defférence sans inégalité". In La Différence culturelle. Une reformulation des débats, 73-84. Wieviorka et Ohana, dir. Paris: Éditions Balland.

Taguieff, P.-A. dir. (1991) Face au racisme. Tome 2. Paris: Éd. La Découverte.

Tinguy, Anne de et Alexandra Picard (1999) "Les Européens de l'Est depuis la chute du Mur". In Immigration et integration, 157-182. Phlippe Dewitte, dir. Paris: La Découverte.

Vala, Jorge, org. (1999) Novos racismos: perspectivas comparativas. Oeiras: Celta Ed.

Wieviorka, Michel (1991) L'espace du racisme. Paris: Éd. du Seuil.

Wieviorka, Michel et al. (1992) La France raciste. Paris: Éd. du Seuil. 